\title{
"Pelo telefone mandaram avisar que se questione essa tal história onde mulher não tá": a atuação de mulheres musicistas na constituição do samba da Pequena África do Rio de Janeiro no início do século $X X$
}

\author{
Rodrigo Cantos Savelli Gomes (UDESC, Florianópolis-SC) \\ rodrigocantos@hotmail.com
}

\begin{abstract}
Resumo: Esta investigação lança-se sobre o samba da Pequena África do Rio de Janeiro nas primeiras décadas do século XX de modo a analisar a atuação das mulheres na região que ficou conhecida como o berço do samba. A partir disso, identifiquei que as Tias Baianas da Pequena África foram mulheres atuantes e influentes no meio musical de sua época, compositoras, instrumentistas, cantoras, agentes transformadoras em um território tido como essencialmente masculino, como é o caso de Ciata, Perciliana, Carmem do Ximbuca, Maria Adamastor, Amélia Aragão, Mariquita, entre outras. Trata-se de um mundo musical feminino desvalorizado, obscurecido por uma construção histórica criada pelas classes superiores, focada nos grandes personagens, nos grandes eventos supostamente mais importantes, no domínio da vida pública, na tradição escrita, com escassos ou mesmo nenhum interesse na face doméstica, na tradição oral, no conhecimento das mulheres.
\end{abstract}

Palavras-chave: mulheres negras no samba; história do samba; Tias Baianas; relações de gênero na música.

"They said over the phone to question this story where women are not present": the role of women musicians in Rio de Janeiro's samba in early twentieth century

Abstract: This research investigates the samba in Pequena África do Rio de Janeiro during the first decades of the 20th century in order to analyze the role of women in the process its formation. From this, I identified that the Tias Baianas from Pequena África were active and influential women in the music of their time, composers, instrument players, singers, people who shaped a territory considered essentially masculine, such as Ciata, Perciliana, Carmem do Ximbuca, Maria Adamastor, Amélia Aragão, Mariquita, etc. This is a musical world where women were devalued, obscured by a historical construct created by the upper classes, focused on the big men, on the major events in the supposedly more important field of public life and the written tradition, with no interest in the domestic face, in the oral tradition, and in the knowledge of women.

Keywords: black women in samba; history of samba; Tias Baianas; gender relations in Brazilian music.. 


\section{1 - Introdução}

A partir da perspectiva dos Estudos de Gênero e da Musicologia, este estudo ${ }^{1}$ tem como objetivo investigar como se estabeleceram as relações de gênero no samba da cidade do Rio de Janeiro nas três primeiras décadas do século XX, período inicial de sua consolidação como símbolo nacional. Com o propósito de questionar a visão ocidental sobre a natureza das construções de gênero que identificam a sexualidade masculina como lócus de poder, apresento uma revisão sobre a importância da atuação das mulheres, bem como a produção de símbolos e marcas da face feminina que constituíram o complexo mundo do samba carioca deste período. Sustento que, apesar do imenso interesse no samba enquanto expressão cultural brasileira, grande parte dos estudos subestimou a importância da produção musical das mulheres e dos elementos femininos constituintes desta manifestação.

Assim como os cânones da música europeia foram consolidados a partir do ponto de vista da masculinidade, privilegiando a figura do homem e do universo masculino em detrimento da mulher e do feminino (MCCLARY, 1991; MELLO, 2007; WILLIAMS, 2007), o imaginário que vem sendo construído a respeito da história do samba e, consequentente, de grande parte da música popular brasileira, vem seguindo um processo semelhante. Trata-se de uma narrativa cujo protagonismo está hierarquizado na figura dos compositores - em sua imensa maioria homens - e suas obras musicais registradas em partituras ou gravações, cuja estrutura seletiva está edificada pelos padrões estéticos estabelecidos pela alta cultura através da categorização 'arte'2. Nesta narrativa, assume segundo plano a produção dos cantores-intérpretes, e terceiro ou nenhum plano a produção dos arranjadores, regentes, instrumentistas, a audiência, a música de tradição oral, a música fora dos padrões consagrados, fora dos grandes centros urbanos $e_{\text {, }}$ conforme apresento aqui, a produção musical feminina. $\mathrm{Na}$ narrativa dos compositores e suas obras primas, as mulheres só começam a ganhar algum destaque no samba a partir da década de 70, quando são apresentadas Clementina de Jesus e Ivone Lara, mais de 50 anos após a gravação e ampla divulgação da música Pelo Telefone ${ }^{3}$, considerada o marco inicial desta resignificação simbólica ao exigir a incorporação da função-autor no universo do samba.

No tocante aos estudos musicológicos, durante muito tempo a musicologia trabalhou no sentido de reforçar 0 paradigma da masculinidade, edificando-se, para isso, em determinados personagens mitológicos masculinos (Bach, Mozart, Beethoven, Brahms, Stravinsky, Chopin, etc.) e um determinado conceito de obra arte, de obra musical, de estética, de beleza, cuja ênfase está na dimensão racional, na objetividade, na seriedade, propriedades frequentemente associadas ao gênero masculino. Neste contexto da música clássica e da musicologia, alguns estudos no campo das relações de gênero e da musicologia feminista (MCCLARY, 1991; MELLO, 2007; WILLIAMS, 2007) têm demonstrado, por exemplo, elementos da teoria musical tradicional onde o masculino está adjetivado em termos como forte, normal e objetivo, enquanto que o fraco, anormal, subjetivo, irregular, fora do comum, 0 desvio da regra, o instável, aparece frequentemente associado ao feminino. Essas propriedades aparecem em estruturas como cadências, temas, terminações, seções musicais, conforme revela MCCLARY(1991) em seu livro Feminine Endings.

A partir dos pressupostos teórico-metodológicos levantados por McClary para o estudo das mulheres na música ${ }^{4}$, apresentarei a seguir uma revisão da bibliografia especializada do samba, buscando notas de rodapé, anexos e temas paralelos a história marginal das mulheres e as representações do feminino no samba carioca das primeiras décadas século XX. 0 fato de haver um limitado conjunto de informações na bibliografia a respeito das mulheres e sua participação no samba, implicou que eu buscasse complementá-lo com a realização pequenas imersões na cidade do Rio de Janeiro entre 2009 e 2010, onde pude buscar informações em instituições como Museu da Imagem e do Som, Biblioteca Nacional, Centro Cultural Cartola, Cidade do Samba, Centro Cultural da Escola de Samba Estação Primeira da Mangueira. Além disso, neste periodo tive a oportunidade de realizar entrevistas não-estruturadas com algumas mulheres influentes do mundo do samba carioca como Vó Maria ${ }^{5}$, Tia Surica ${ }^{6}$ Áurea ${ }^{7}$, Dona Neném ${ }^{8}$, Maria Moura $^{9}$ além de conversas informais com Lygia Santos ${ }^{10}$, Jurema Werneck ${ }^{11}$, Nilcemar Nogueira ${ }^{12}$. Tal imersão se aplicou no sentido de buscar uma complementação e não de realizar uma etnografia, de modo que o trabalho mantém a característica de se apresentar como um estudo de revisão histórico-bibliográfica.

Apresento a seguir um exame das relações de gênero no samba carioca tendo como recorte a região que ficou conhecida como "Pequena África do Rio de Janeiro"14. Com este recorte, mostrarei que as relações de gênero neste contexto - assim como em outros territórios hegemonicamente afro-brasileiros - se configuravam de uma forma diferente daquela estabelecida pela tradição centro-europeia (incorporada pela alta sociedade brasileira) e que tal especificidade pode ter exercido uma influência significativa na produção musical deste contexto. Para isso, tomarei como referência alguns estudos que se aprofundaram nos fundamentos religiosos e culturais das tradições afro-brasileiras como THEODORO (1996 e 2008), LANDES (2002), SANTOS (2006), AMARAL (2007), MATOS (2007) que apontam para a possibilidade de tais territórios serem regidos por uma espécie de matriarcado. Neste sentido, argumentarei que tal produção musical era constituída por uma expressiva participação feminina, e que este samba era menos fragmentado em relação aos papéis de gênero. $A$ ideia do samba como um território masculino e de produção de masculinidades, como a literatura a cerca da música popular brasileira sugere, seria, portanto, uma construção posterior que tem mais haver com a invenção do samba como produto de uma identidade nacional/brasileiro do que com o samba enquanto expressão cultural afro-brasileira. 


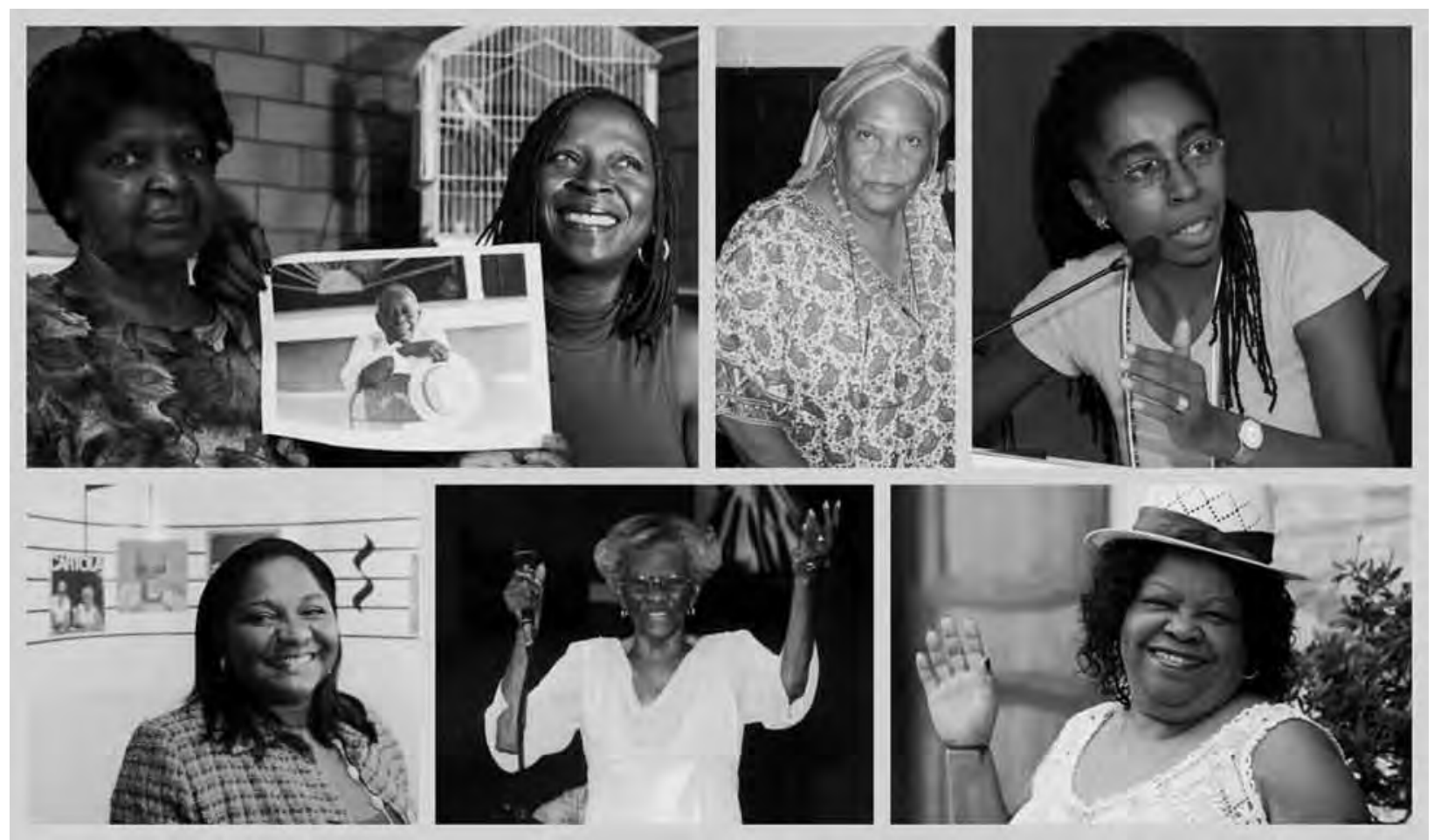

Ex.1 - Fotos de algumas das mulheres contatadas para esta pesquisa. Da esquerda para a direita, linha de cima: Dona Neném, Áurea, Maria Moura, Jurema Werneck. Linha de baixo: Nilcemar Nogueira, Vó Maria, Tia Surica.

\section{2 - Uma Pequena África que dá samba}

A maioria dos estudos culturais sobre o Rio de Janeiro das primeiras décadas do século XX aponta a região que ficou conhecida como "Pequena África" como a principal matriz na formação de uma cultura popular urbana no Rio de Janeiro entre o fim do século XIX e início XX. Trata-se de um território que, no periodo em questão, foi ocupado majoritariamente por afro-brasileiros, entre eles, migrantes de diversas partes do Brasil. Habitaram principalmente as regiões da Pedra do Sal e Saúde, localidade situada perto do cais do porto. Em seguida, este território se estendeu para as ruas da Cidade Nova e Campo de Santana, como as ruas Visconde de Itaúna e Senador Eusébio, Santana e Marquês do Pombal, convergindo na Praça Onze de Junho e, mais tarde um pouco, indo para os morros em torno do Centro. Neste contexto, um determinado grupo de migrantes baianos se tornou um dos principais protagonistas desta narrativa.

A concentração em torno destes baianos tomou uma dimensão ainda maior a partir da publicação, em 1983, do livro de Roberto Moura, Tia Ciata e a Pequena África do Rio de Janeiro. 0 trabalho de MOURA foi um dos primeiros a situar a trajetória do grupo baiano em seu processo histórico e social, tornando-se um clássico e referência obrigatória nos estudos sobre cultura popular brasileira. Seguindo esta tendência, a maioria dos pesquisadores que contribuiram para a construção histórica do samba (SODRÉ, 1998; SANDRONI, 2001; PEREIRA, 2003; M. MOURA, 2004; CUNHA, 2004; DINIZ, 2006; CALDEIRA, 2007; VIANNA, 2007) passou também a atribuir a este contexto o meio principal onde o samba teria encontrado um terreno propício para seu desenvolvimento enquanto gênero musical e prática sócio-cultural, culminando na sua posterior projeção como gênero musical característico da cultura brasileira, símbolo da identidade nacional, conforme aponto nos trechos abaixo:

0 samba desenvolveu-se no Rio de Janeiro a partir de redutos negros (os baianos do bairro da Saúde e da Praça Onze), como já foi acentuado. Nas festas familiares, tocava-se e dançava-se o samba em seus diversos estilos, para o divertimento dos presentes (SODRÉ, 1998, p. 35).

Foi nessa região "reterritorializada" do Rio de Janeiro, área periférica habitada por excluidos, ex-escravos, judeus de várias partes do mundo, enfim toda sorte de pessoas que não participava da vida social da nossa capital, que o samba emergiu. [...] Nesta periferia se reuniam os futuros bambas: Ciata, Hilário Jovino [...], João da Baiana, Sinhô, Heitor dos Prazeres e Donga, nomes que ecoam até hoje nos redutos do samba. Foram eles que fizeram de uma atividade quase marginal uma expressão de arte (M. MOURA, 2004, p. 58).

0 cenário dessa epopeia foi a cidade do Rio de Janeiro, e os atores principais deixaram seus nomes gravados: Donga, Sinhô, Pixinguinha, Ismael Silva [baianos ou filhos das Tias Baianas]. Foram eles os responsáveis pela construção do samba (CALDEIRA, 2007).

[...] fase pioneira da criação do gênero no Rio de Janeiro, no início do século $X X$, com o grupo de imigrados baianos cuja representante mais ilustre foi a famosa Tia Ciata. Essa fase pioneira se consolida no ano de 1917, que foi o ano do lançamento de Pelo telefone, considerado por todos como o marco inicial do gênero. É a partir de então que a palavra "samba" entra no vocabulário da música popular (SANDRONI, 2001, p. 15).

Os compositores pioneiros do samba [...] vivenciaram e construíram todo um legado cultural que a Cidade Nova 
simbolizou no universo carioca. Frequentaram, sem exceções, as casas das famosas baianas festeiras, espaço de acolhida material, espiritual e cultural importantíssimos para a história cultural negra e do samba (DINIZ, 2006, p. 27).

Atualmente, essa centralidade em torno dos baianos vem sendo revista por alguns estudiosos que passaram a sugerir outras visões e experiências na formação deste repertório cultural tão importante para a constituição da identidade nacional. Para citar alguns: MUKUNA (2006) que apresenta um estudo sobre a influência dos escravos de etnia banto para música popular brasileira; CUNHA (2001), que destaca as diferentes práticas carnavalescas das populações pobres e das camadas altas do Rio de Janeiro, revelando suas contribuições na formação do carnaval brasileiro; GOMES (2003), que revela a importância de outros territórios culturais no processo de formação do samba, como as regiões situadas em torno da Portela, Mangueira e Império Serrano.

Ciente desta lacuna, o presente estudo manterá o foco no núcleo baiano da Pequena África do Rio de Janeiro, procurando, quando possível, contrapor com dados de outros contextos culturais e geográficos. Se a contribuição feminina nas práticas musicais desta região é pouco valorizada, apesar da literatura ter sido amplamente direcionada para esta realidade, que dirá em contextos ainda pouco explorados. Este estudo não pretende dar conta desta problemática, por isso, a partir de agora vou me concentrar em alguns aspectos das relações de gênero no contexto da Pequena África do Rio de Janeiro, em especial, as conexões entre o sagrado e o profano em torno das práticas musicais ali estabelecidas.

\section{3 - Tias Baianas que lavam, cozinham, batucam, dançam, cantam, tocam e compõem}

Estudos sobre religiosidade têm demonstrado que em diversos territórios majoritariamente por afrobrasileiros a mulher negra costuma possuir um elevado status social, (THEODORO, 1996; LANDES, 2002; SANTOS, 2006; MATOS, 2007). Nestes contextos - como é o caso também da Pequena África do Rio de Janeiro - não se sustenta o modelo burguês de familia que delega à mulher o espaço do lar, a criação dos filhos e a submissão, e ao homem o trabalho, a subsistência da família e o controle sob a terra e os bens. Inúmeras razões costumam ser apontadas no processo de consolidação deste diferencial da mulher negra.

Alguns autores, especialmente não acadêmicos, referemse a uma herança cultural que teria sido trazida das terras africanas e preservada em solo brasileiro pelos escravos e seus descendentes. Embora na maioria das etnias da África Negra a posição da mulher seja inferior à dos homens,

Por toda a África à mulher se deram tradicionalmente grandes oportunidades (como propriedade e controle de hortas e pomares, mercados, negócios domésticos, sociedades secretas) e reconhecimento oficial (de sacerdotisa e médium, os paços de rainha e outras entidades que tratam de interesses femininos); por vezes a mulher as partilhava com os homens. Era assim nas complexas sociedades da África Ocidental de onde veio, ou descendia, grande parte da população escrava (LANDES, 2002, p. 349).

Entretanto, tem prevalecido na academia (VELOSO, 1990; AMARAL, 2007; LANDES, 2002; HITA, 2004, WOORTMANN, 1987) a ideia que, sob a escravidão, o homem negro experimentou a segregação familiar, a violência, 0 excesso de trabalho e humilhações mais profundamente do que as mulheres negras. A desvalorização da posição e oportunidades para 0 homem negro teria sido compensada pela intimidade que a mulher tinha com a casa grande, principalmente em função do trabalho doméstico desempenhado por elas, sempre essencial para subsistência da família dos senhores.

Mesmo décadas após a abolição, essa relação desigual permaneceu no mundo afro-brasileiro. A mulher negra rapidamente conseguiu se armar "em torno da infraestrutura das casas 'de familia', senhoriais e burguesas, como cozinheiras, lavadeiras, copeiras ou em qualquer outro serviço eventual requisitado" (MOURA, 1995, p. 72-73), tornando-se a principal provedora de sustento financeiro e referência familiar conforme argumentam VELOSO (1990), AMARAL (2007) e LANDES (2002).De fato,

\footnotetext{
[...] a mulher negra exercia, inclusive, uma importante influência modernizadora na cultura brasileira, já que por tradição herdada dos costumes africanos e por contingências da escravidão e do período pós Abolição, eram economicamente ativas e independentes. Eram mulheres que tomavam suas próprias decisões, o que lhes era possivel porque para viverem contavam com seu próprio trabalho, geralmente como cozinheiras, lavadeiras, costureiras, amas-de-leite, amas-secas, vendedoras de acarajé, quindins, canjica e outros quitutes, criadas, padeiras, quitandeiras etc. Esta liberdade e independência ecoavam em sua autoridade no candomblé (e vice-versa), oferecendo o contraponto matriarcal ao desabrido domínio dos homens em toda a vida nacional e latina da época (AMARAL, 2007).
}

Desse modo, revela-se em muitas camadas populares afro-brasileiras uma espécie de matriarcado que não reproduz nem o modelo africano nem, muito menos, o modelo patriarcal de família importado dos colonizadores europeus.

A ideia de matriarcalidade ${ }^{15}$ que aplico ao contexto da "Pequena África do Rio de Janeiro" refere-se a um conjunto de relações, amizade, parentesco sanguíneo, parentesco religioso (pai, mãe e irmãos de santo) que está centralizado na figura de uma matriarca Tiamãe-avó, que é o centro das interações de uma rede a partir da qual se multiplicam as relações entre todos os outros membros. Nesta configuração, o papel das Tias Baianas foi imprescindivel para a sobrevivência do grupo, tendo se tornado a figura central para a permanência das tradições afro-brasileiras. Sua condição Ihe concedeu situação econômica privilegiada, a posição central na casa, na comunidade e nas práticas religiosas, de modo que nos terreiros ou eram mães-de-santo (principal chefe espiritual) ou ocupavam os principais cargos subsequentes. 
Estudos sobre o samba do início do século XX costumam fazer inúmeras referências às Tias Baianas, especialmente mulheres como Tia Ciata, Tia Carmem, Tia Amélia, Tia Perciliana. Essas baianas estão entre personalidades consideradas mais importantes das camadas populares na virada do século XX na cidade do Rio de Janeiro, frequentemente proclamadas como 'matriarcas do samba', tidas como influentes e poderosas. No entanto, apesar da influência destas mulheres no campo político e religioso, raras indicações são encontradas referentes à presença delas no cenário musical. Apesar do explicito reconhecimento da importância das Tias Baianas na literatura e do alto status que a mulher negra exercia no meio afro-brasileiro, quando o assunto é a prática musical as mulheres deixam a cena. Há certo consenso, um imaginário construido do samba carioca no início do século XX que coloca as Tias Baianas como as responsáveis por gerar a estrutura propícia para o rito, protegendo, abrigando, mantendo a comida e a bebida, enquanto que o fazer musical é assumido pelos homens. Quando a roda se forma, as mulheres são mencionadas na dança e, quando muito, constituindo o coro e as palmas. Revelam-se, então, inúmeras personalidades masculinas, como Donga, Sinhô, João da Baiana, Pixinguinha, Hilário Jovino, Heitor dos Prazeres, Germano, Caninha, Almirante, Baiano. Alguns destes inclusive proclamados 'Rei do Samba' como Sinhô, 'Imperador do Samba' como Caninha ou 'criador do samba' no caso do Donga.

Apesar de muitos pesquisadores do samba e do carnaval brasileiro citarem a influência das Tias Baianas, essa menção é feita de um modo genérico. Não há um aprofundamento sobre quem eram essas mulheres. Geralmente seus nomes aparecem nas páginas introdutórias ou em associação aos grandes homens sambistas (mães ou esposas). Apenas uma delas, a Tia Ciata (Hilária Batista de Almeida), foi posta realmente em destaque, fato que a tornou o modelo central ou a figura mais representativa das baianas desta época (GOMES, 2003). Por essas razões e, por falta de acurada investigação sobre as demais baianas, há uma significativa quantidade de informações a respeito das práticas afro-brasileiras na casa de Tia Ciata, sobre sua vida social e política, sobre sua familia, suas origens e seus costumes. Portanto, é sobre ela que primeiro investirei a fim de trazer algumas evidências a respeito de sua imersão no cenário musical.

\section{4 - Pelo telefone uma mulher mandou avisar}

A famosa polêmica gerada por causa da gravação da música Pelo Telefone - proclamada como primeiro samba a ser gravado no país, registrado com a autoria de Donga e Mauro de Almeida - sugere que Tia Ciata teria sido uma baiana que se dedicava também à composição, apesar de nunca ter sido assim nomeada em suas biografias e escritos sobre a história do samba. Assim que lançada, no ano de 1917, Ciata, João da Mata, Germano e Hilário, reclamaram a autoria deste samba, fato divulgado discretamente num canto de página do Jornal do Brasil em 4 de fevereiro de 1917, por meio da seguinte nota:

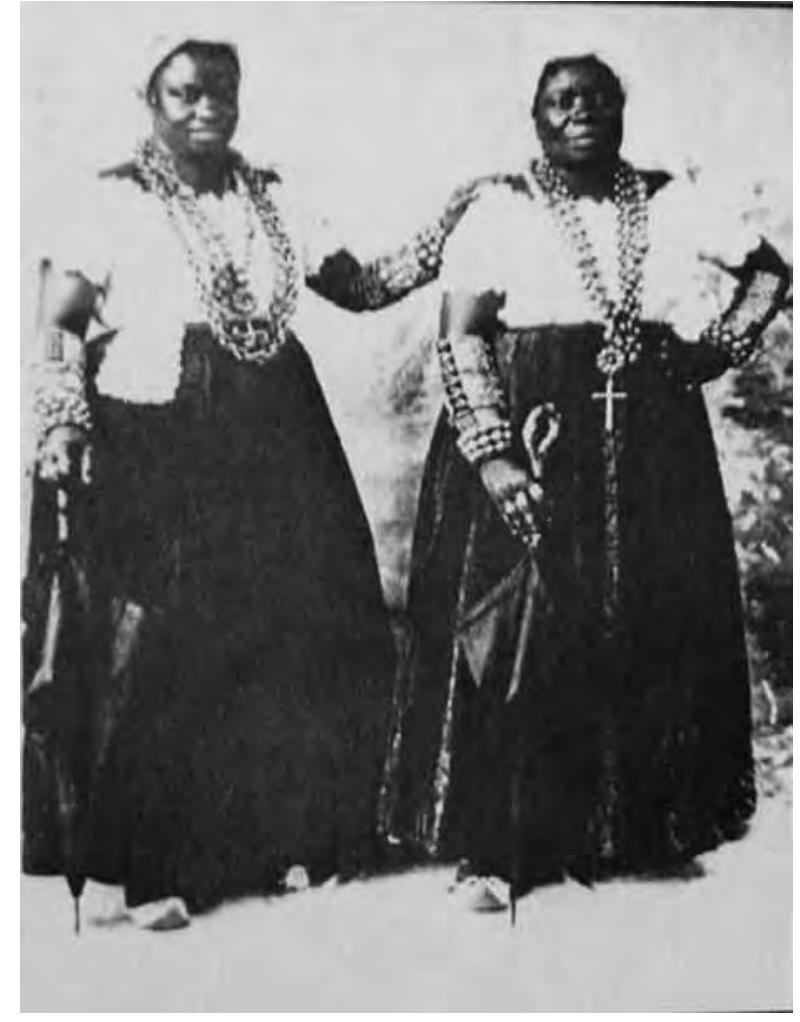

Ex.2 - Imagem das Tias Baianas do início do século $X X^{16}$

Do Grêmio Fala Gente recebemos a seguinte nota: Será cantado domingo, na Avenida Rio Branco, o verdadeiro tango Pelo Telefone, dos inspirados carnavalescos, o imortal João da Mata, o maestro Germano, a nossa velha amiguinha Ciata e o inesquecivel e bom Hilário; arranjado exclusivamente pelo bom e querido pianista J. Silva (Sinhô), dedicado ao bom e lembrado amigo Mauro, repórter de Rua, (falecido) em 6 de agosto de 1916, dando ele o nome de Roceiro (JORNAL DO BRASIL citado por MOURA, 1995, p.124).

Além da nota de jornal, a própria letra desta versão parodiada da música Pelo Telefone sugere a participação efetiva de Ciata nesta composição.

\footnotetext{
Pelo telefone / A minha boa gente / Mandou avisar / Que o meu bom arranjo / Era oferecido / Pra se cantar. Ai, ai, ai, / Leve a mão na consciência, / Meu bem, / $\mathrm{Ai}$, ai, ai, / Mas porque tanta presença, / Meu bem? Ó que caradura / De dizer nas rodas / Que esse arranjo é teu! / É do bom Hilário / E da velha Ciata / Que o Sinhô escreveu. Tomara que tu apanhes / Para não tornar afazer isso, / Escrever o que é dos outros / Sem olhar o compromisso.
}

A polêmica em relação à autoria deste samba e se é mesmo o primeiro samba ou não a ter sido gravado, são temas que despertaram grande interesse nos estudos que tratam da música popular brasileira deste período. No entanto, a presença de uma Tia Baiana reclamando a autoria da música junto a sambistas consagrados foi pouco valorizada.

Notas de Mário de Andrade - que, segundo relatos, frequentou a Casa de Tia Ciata - podem reforçar essa aproximação de Ciata com a música. Embora o foco de seu relato fosse descrever os rituais de Macumba no Rio de Janeiro, Andrade refere-se casualmente à Tia Ciata 
como uma eximia compositora. Inclusive, introduz outra façanha da velha baiana: a intimidade com violão.

\begin{abstract}
Uma das mais recentes mães-de-santo (pois que podem também ser mulheres) famosas foi tia Ciatha, mulher também turuna na música dizem. Passava os dias de violão no colo inventando melodias maxixadas e falam mesmo as más línguas que muito maxixe que correu Brasil com nome de outros compositores negros era dela apropriações mais ou menos descaradas (ANDRADE, 2006, p. 150).
\end{abstract}

No seu principal romance, Macunaíma, o herói sem caráter, Mario de Andrade retrata uma visita que sua personagem-título faz a casa de Tia Ciata para participar de uma cerimônia de macumba. Na descrição, reforça a façanha de Ciata ao violão e, novamente, acrescenta outro feito: sua cantoria.

Era junho e o tempo estava inteiramente frio. A macumba se rezava lá no Mangue do zungu da Tia Ciata, feiticeira como não havia outra, mãe-de-santo famanada e cantadeira ao violão. Às vinte horas Macunaíma chegou [...] foi de quatro saudar a candomblezeira imóvel sentada na tripeça, não falando um isto. Tia Ciata era uma negra velha com um século no sofrimento, já vovó e galguincha com a cabeleira branca esparramada feito luz em torno da cabeça pequetita (ANDRADE, 2004, p. 07).

Carmem do Ximbuca, contemporânea e irmã-de-santo de Ciata, em depoimento a Roberto Moura reafirma o imponente canto da baiana, versando e improvisando nas rodas de samba de sua casa. Segundo ela, Tia Ciata

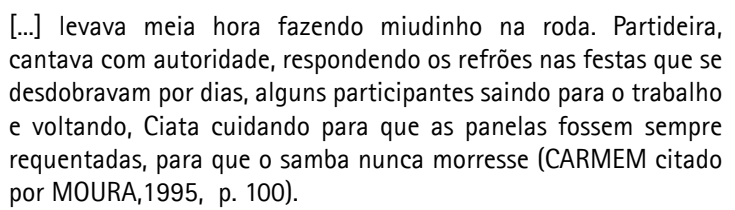

[...] levava meia hora fazendo miudinho na roda. Partideira, cantava com autoridade, respondendo os refrões nas festas que se desdobravam por dias, alguns participantes saindo para o trabalho e voltando, Ciata cuidando para que as panelas fossem sempre requentadas, para que o samba nunca morresse (CARMEM citado por MOURA, 1995, p. 100).

As evidências apontam que Tia Ciata além de cozinheira, dançarina e uma boa festeira, foi uma mulher atuante e influente no meio musical de sua época. Mais adiante, vou mostrar indícios que sugerem que Ciata não era um caso isolado entre as mulheres. Contudo, é preciso ressaltar que, se sobre Ciata - a baiana mais famosa - as informações foram encontradas com certa dificuldade, sobre as demais Tias Baianas, vão ficando cada vez mais escassas.

\section{5 - Pastoras que sustentam o samba}

Antes de continuar apresentando as mulheres musicistas da 'Pequena África', quero abrir um parêntese para comentar a respeito de um dos papéis desempenhados pelas mulheres no samba do final do século XIX e início do $X X$, uma ocupação fundamentalmente feminina. Trata-se de um coro feminino, chamado no contexto do samba por 'pastoras', responsável por cantar a melodia em diversas práticas musicais afro-brasileiras. As pastoras ganharam destaque principalmente no samba de quadra e nos desfiles dos ranchos carnavalescos. A partir da década de 1960, este coro passou a integrar as Escolas de Samba, onde manteve a designação 'pastoras', porém com uma mudança significativa em relação à função e hierarquia, conforme argumento logo a seguir.
Assim com muitos elementos do samba se originaram das práticas religiosas afro-brasileiras - sobre isso aprofundarei mais adiante ao comentar o sobre o papel da mulher na percussão - é possivel que seja a partir do terreiro que o coro feminino se propagou para o samba. Embora nas práticas religiosas do terreiro o canto não seja privilégio de nenhum dos sexos (AMARAL e SILVA, 2008), a voz feminina, por ser em maior número e entoada em um registro mais agudo, se sobrepõe facilmente à dos homens, de modo que o que se ouve durante todo o ritual é praticamente um coral de mulheres.

Eram as Tias Baianas, mães e filhas-de-santo, que constituiam a base vocal nos ranchos cariocas das primeiras décadas do século XX. Entre as mais conhecidas, Maria Adamastor ${ }^{17}$, rainha dos diretores de rancho, assumiu a responsabilidade de pastora do Reinado de Siva e, além de pastora, neste mesmo rancho se destacou como mestre-sala. Amélia do Aragão ${ }^{18}$, conhecida como uma das mais importantes figuras do mundo do samba que atuavam na Cidade Nova, cantadeira de modinhas. Tia Carmem ${ }^{19}$, mulher que viveu toda sua vida engajada no carnaval carioca, segundo contam, "não cantou no rádio porque não quis,convites não faltaram" (COSTA citado por SILVA, 2009, p. 18).

Nos desfiles dos ranchos carnavalescos e até o período inicial de formação das primeiras escolas de samba, as pastoras cantavam a primeira parte e a segunda ficava a cargo dos chamados versadores ou mestre do canto que, na maioria das vezes, lançavam mão de versos improvisados, uma prática comum no samba deste período. Duas partes, portanto, eram perfeitamente distinguiveis "a primeira de caráter coral, destinadas às pastoras, e a segunda de caráter solista, destinada a um cantor de sexo masculino" (DOSSIÊ DAS MATRIZES DO SAMBA NO RIO DE JANEIRO, 2006, p. 40). Não se tinha por costume cantar uma única música como hoje fazem as escolas de samba, várias melodias podiam ser puxadas, por vezes, uma verdadeira miscelânea de sambas. Na medida em que os ranchos foram crescendo, as vozes das pastoras e dos versadores não podiam mais ser ouvidas por todos os integrantes durante todo 0 percurso do desfile, o que fazia com que, por vezes, parte do grupo mais próxima ao palanque estivesse cantando uma parte, enquanto que a turma da frente ou de trás estivesse cantando outro verso. Com isso, a possibilidade de cruzamentos (ou sobreposições) rítmicos, melódicos e de outras espécies era constante nestes desfiles. Assim que a tecnologia permitiu, as escolas passaram a trazer um carro de som para amplificar as vozes. Porém, neste processo, as pastoras perderam o destaque como condutoras principais. Desde 1946

a presença de versos improvisados foi oficialmente proibida nos desfiles. Mas é provável que o processo tenha sido paulatino, e que algumas escolas já tivessem, antes desta data, introduzido o hábito de desfilar com as segundas partes previamente compostas (DOSSIÊ DAS MATRIZES DO SAMBA NO RIO DE JANEIRO, 2006, p. 37). 
A responsabilidade de manter, sustentar o samba na avenida passou a se concentrar na figura de um homem, o solista, chamado de intérprete oficial, ou popularmente por "puxador", embora sempre acompanhado de um grupo de apoio com mais quatro a seis homens. As pastoras passaram então para um plano secundário. Um grupo bem mais reduzido de mulheres, de três a seis (não mais 30 ou 40 como antes) passou a fazer um contracanto ou dobrar a voz do solista em alguns trechos selecionados, com a finalidade de dar um apoio ao cantor principal ou abrilhantar algumas passagens do sambaenredo. 0 termo "pastoras" se manteve, mas a função e 0 status da mulher cantora nas Escolas de Samba sofreram notável transformação. De fundamentais passaram a figuras dispensáveis e opcionais. A partir de então foram raros os casos de mulheres como "puxadoras" de samba, fazendo com que esta posição se tornasse essencialmente masculina.Algumas razões costumam ser levantadas para justificar essa inversão dos papéis de gênero.

Em primeiro lugar, as mulheres teriam menor resistência vocal para aguentar os quase 90 minutos de desfile, enquanto que a voz masculina teria maior peso e força. Pude verificar a atribuição de força e potência à voz masculina - portanto, ideal para conduzir o canto nos desfiles da avenida - em um estudo anterior sobre o samba na cidade de Florianópolis (ver: GOMES e PIDEDADE, 2010). As pastoras da escola de samba entrevistadas para aquele trabalho afirmaram que os homens subestimavam as vozes femininas para, com isso, garantir sua posição de destaque. Segundo elas:

eles acham que a gente não é capaz de cantar um samba inteiro na avenida pra ajudar. Eles dizem que nossa voz não tem peso igual à de um homem (GOMES E PIEDADE, 2010, p. 09); Falam que a mulher tem voz aguda, não pode puxar samba-enredo, que é homem que tem que puxar. A gente não canta todas as partes do samba-enredo. Eles acham que a gente não tem voz pra isso (GOMES E PIEDADE, 2010, p. 09).

Na mesma direção, Tia Surica, pastora da Escola de Samba Portela do Rio de Janeiro, em depoimento para esta pesquisa, apontou o processo de aceleração do samba-enredo como fator principal para a hegemonia masculina na posição de puxadores. Ela conta que puxou o único samba-enredo feito por Paulinho da Viola para a Portela, intitulado Memórias de um sargento de milícias,ano que a escola foi campeã do carnaval. Ao comentar sobre mulheres cantoras de samba-enredo, ela declarou que

\begin{abstract}
naquela época havia mais porque o samba era cadenciado, não era essa correria que é agora. Então você tinha aquele potencial para cantar um samba-enredo na avenida. Hoje em dia não. E não tinha cronometragem. Agora não, são 80 minutos, e mulher não tem mais fôlego pra puxar um samba na avenida. 0 samba agora é corrido. Eu sou uma que não tenho mais condições, já deu o que eu tinha que dar (TIA SURICA). ${ }^{20}$
\end{abstract}

Em seguida, Surica menciona algumas mulheres que cantaram samba-enredo pelas escolas de samba mais ou menos no mesmo período que ela, como Tacira pela Portela, Silvana pela Império Serrano, Elza Soares pela
Mocidade Independente. Também merece lembrar que Ivone Lara cantou pela Escola Império Serrano em 1961, conforme ela mesma relata em seu depoimento ao MIS em 1978. ${ }^{21}$ Entretanto, estas participações foram esporádicas e o que se percebe é que mesmo as participações casuais de mulheres têm sido menos frequentes deste então nesta posição. Se há alguma razão biológica para esta inversão de papéis, ela precisa de uma fundamentação mais consistente, pois parece contraditório o fato das mulheres terem sido designadas a conduzir o canto principal antes dos avanços tecnológicos, justamente quando a potência e resistência da voz eram fundamentais. A amplificação elétrica promoveu justamente o contrário, ou seja, que vozes antes consideradas inadequadas por serem potencialmente fracas para a prática musical tornassem viáveis, como foi o caso da bossa-nova, onde os artistas podem cantar sussurrando. É possível que a voz feminina fosse considerada a ideal antes da amplificação elétrica devido a esta soar uma oitava acima. Por ser mais aguda é mais facilmente perceptivel ao ouvido humano, que tem mais facilidade em reconhecer as frequências agudas do que as graves quando próximo à fonte sonora, embora 0 som grave se propague a distâncias maiores.

É mais provável que decisões estético-ideológicas tenham pesado mais nesta configuração. Conforme dito anteriormente, o samba do início do século XX estava muito próximo às práticas do terreiro, uma aproximação indesejável na construção de um samba que se pretendia símbolo nacional para os ideais da época. Nos terreiros, as vozes femininas tomavam (e tomam) maior destaque que as masculinas de modo que ao entrar num destes centros praticamente o que se ouve é um coro feminino. Tal característica se manteve no samba por um bom período. Monarco da Portela, conta que em sua época de auge

As pastoras é que mandavam. Se elas não cantassem não acontecia nada, não adianta. A gente cantava um samba lá, se elas não quisessem cantar, não adiantava porque a voz feminina é que é o grupo, né?! Ficava uma porção de homem cantando, não tinha graça. [...] Se elas gostassem, elas se animavam e cantavam, e aquilo ia, depois tornava-se um sucesso no terreiro por causa delas (MONARCO DA PORTELA citado por VELHA GUARDA DA PORTELA EM "O MISTÉRIO DO SAMBA", 2008). ${ }^{22}$

Áurea, pastora da velha-guarda da Portela, em entrevista para esta pesquisa, confirma essa versão:

\begin{abstract}
Antigamente, quando os ensaios eram mais voltados para ensaiar o samba de quadra, então tinha que ter as pastoras. Até a formação era diferente, era um círculo. As mulheres ficavam no circulo ali rodando, cantando o samba, evoluindo, mas sempre no círculo. Quando lançavam o samba na quadra, tinha que ter as mulheres pra fortalecer o samba, até pra influenciar na escolha, porque samba que elas não gostavam, elas não cantavam. 0 samba não ia pra frente, elas boicotavam mesmo. [...] Papai tinha um fã clube [...] aí elas passavam: 'só canto samba de Manacéa'. [...] Agora não tem mais, é impossível uma escola que recebe 2.000 pessoas fazer isso. [...] Hoje acabou isso, nos ensaios não tem mais pastoras, porque o ensaio agora é voltado para a multidão (ÁUREA)..$^{23}$
\end{abstract}

0 que se percebe nestes depoimentos é que, à medida que o samba vai se afastando do terreiro e se encaminha para o 


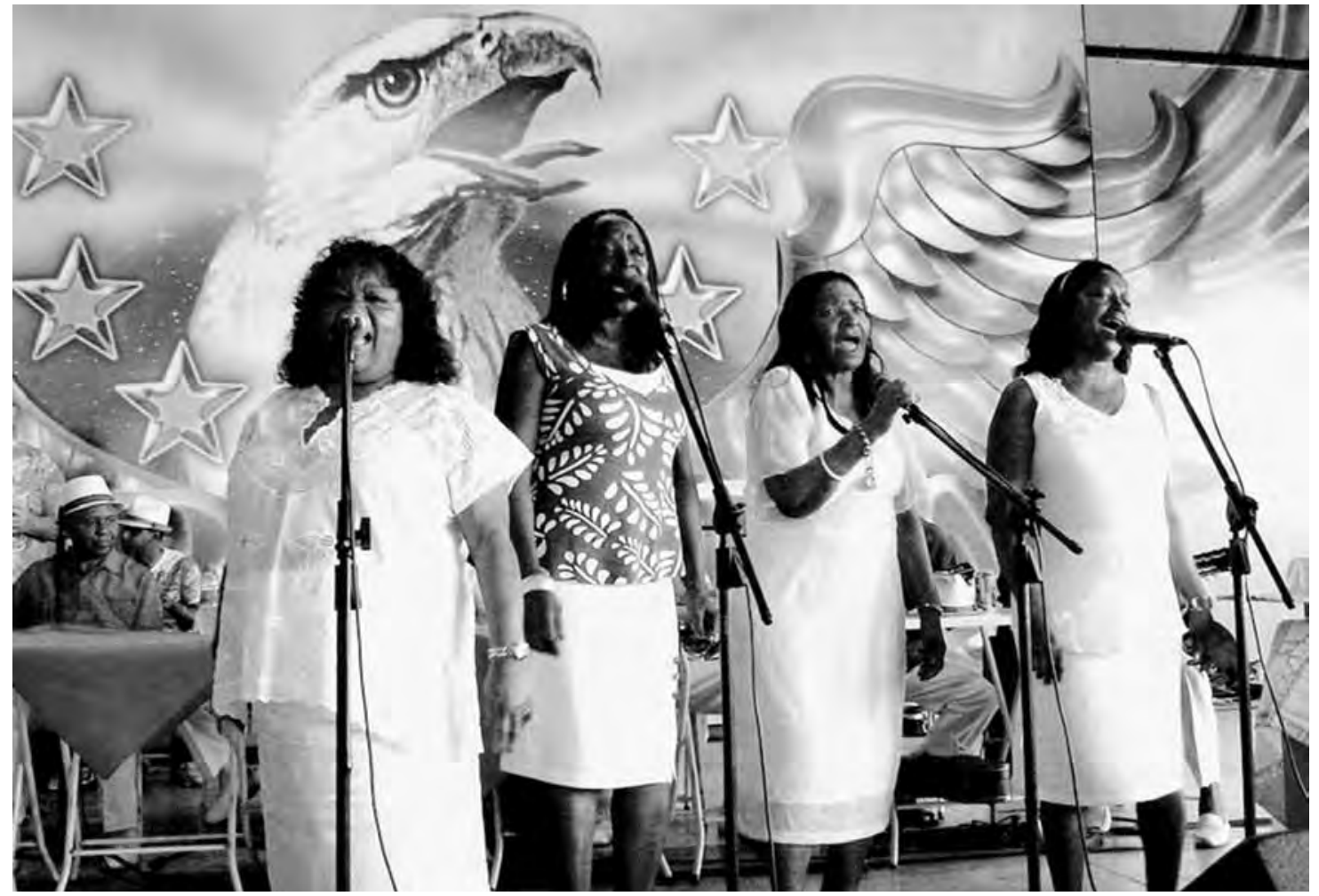

Ex.3 - Foto das Pastoras da Velha-Guarda da Portela em 06 de Setembro de 2008, Madureira, Rio de Janeiro. Da esquerda para direita: Tia Surica, Áurea Maria, Tia Doca, Neide.

Fotografia: Priscilla Guerra. Copyright ${ }^{\odot}$ Todos os direitos reservados. ${ }^{24}$

palco ou avenidas, o coro feminino vai perdendo seu lugar enquanto elemento fundamental para o samba acontecer.

Em segundo lugar, uma crença - que iniciou com a era mecânica de gravação e que se estendeu por parte da fase elétrica - que a voz feminina, por ser mais aguda, não era bem captada pelos microfones e equipamentos de som, o que a tornava estridente e desagradável aos ouvintes. Segundo CARDOSO FILHO (2007), muitos trabalhos sobre a produção de músicas populares em estúdio "afirmam que a ausência feminina ocorria, entre fatores de cunho sociocultural, devido às condições técnicas das gravações mecânicas". Entretanto, o autor afirma que "as frequências agudas não eram um problema para a gravação e a reprodução mecânica. Muito pelo contrário, o problema consistia na captação dos sons graves". Após realizar diversas as análises espectrográficas do repertório brasileiro do início do século XX o autor não encontra razões explícitas que permitam

\footnotetext{
[...] reduzir a participação feminina exclusivamente a questões tecnológicas, uma vez que estas não eram um problema generalizado. Muitas das gravações femininas no periodo mecânico são tão qualitativamente boas quanto às masculinas. [...] Os resultados das comparações com gravações de cantores não foram suficientes para colocá-los esteticamente em superioridade em relação às mulheres (CARDOSO FILHO, 2007).
}

Com isso, CARDOSO FILHO (2007) argumenta que questões de cunho sócio-cultural devem ter sido mais relevantes para a reduzida participação feminina nas gravações deste período do que as tecnológicas. É possivel notar que a justificativa da incompatibilidade da voz feminina com a tecnologia disponível da época vem ganhando seu lugar nos estudos sobre a música popular brasileira, em especial aqueles que tratam das mulheres na música como, por exemplo, em WERNECK (2007) e SOUZA (2006), conforme os trechos abaixo:

0 número reduzido de mulheres que produziram gravações a esta época poderia estar vinculado às limitações da tecnologia aplicada para o caso da gravação de vozes. Enquanto esteve limitada ao registro de músicas instrumentais, foi possivel para Chiquinha Gonzaga ter acesso a esta tecnologia e manter sua participação destacada. Já quando se passou ao registro de canções, as limitações dos equipamentos, que requisitavam uma forte projeção de vozes, um modo grave e operístico de cantar, gritado, por tenores e baritonos, para que o equipamento pudesse ser alcançado e o registro feito, as mulheres não tiveram participação correspondente (WERNECK, 2007, p. 154).

0 destaque para os cantores de grande potência vocal e de voz grave foi evidenciado por questões tecnológicas. Neste sentido, além da questão social que ditava um padrão representativo da mulher dita "honesta" como aquela que estivesse circunscrita ao espaço doméstico, havia ainda uma questão tecnológica que limitaria o acesso da mulher à possibilidade de realizar gravações mecânicas (SOUZA, 2006).

Estes conflitos afirmam a música como um campo das disputas políticas, onde o campo político se consolida como aquele que permeia e penetra todos os outros campos, do artístico ao ritualístico. Como campo de disputa, a música pode ser usada como uma forma particular de poder, usada para limitar ou ampliar o acesso 
e o conhecimento social, ritual e político de mulheres e homens (ROBERTSON, 1989). No caso do samba, pode-se dizer que houve um empoderamento dos homens a uma função que antes era designada às mulheres. Curiosamente, em uma pesquisa que realizei recentemente numa escola de samba de Florianópolis (GOMES e PIEDADE, 2010), o naipe das vozes (puxadores e pastoras) se revelou como um dos campos mais conflituosos no que se refere às disputas de poder entre os gêneros. As pastoras desta escola de samba demonstraram imensa insatisfação em relação a sua posição e a pouca valorização de seu papel dentro da escola. Já na bateria, ou seja, nos instrumentos de percussão, houve maior consenso entre as partes. As ritmistas - quase todas concentradas em torno do naipe dos chocalhos -, estavam de acordo que o chocalho é o lugar feminino, enquanto que os tambores em geral (caixa, repenique, surdo), eram mais adequados aos homens.

Enquanto que o papel de conduzir o canto nas escolas de samba foi apoderado num momento de reordenação interna - pela competitividade estimulada pelas premiações (concursos); pelos ideais nacionalistas que o samba precisou integrar; pelas inovações tecnológicas -, vou mostrar mais adiante que a hegemonia masculina na percussão pode encontrar sua razão, ao menos em parte, na mitologia africana e nas convenções instituídas nos terreiros.

\section{6 - As donas dos tambores, os donos dos toques}

Intrigado pelas poucas referências às mulheres sambistas no contexto da casa das Tias Baianas, Nei Lopes em uma entrevista publicada nos anexos de seu livro questiona Marinho da Costa Jumbeba (neto de Ciata) sobre a presença de mulheres nas rodas de samba da época de sua avó, fazendo-Ihe a seguinte pergunta: "E as mulheres faziam partido-alto?". Ele responde:

\begin{abstract}
Fazia! Ah! Era a Mariquita, Sinhá Velha... Maria Adamastor era uma grande sambista, que fazia grandes sambas, compreendeu? A minha tia, por exemplo, a Mariquita, tocava muito pandeiro, compreendeu? Ela às vezes em casa, só brincando, fazia um grande partido-alto. Só com um pandeiro e os cantos. Mas tinha muita senhora que naquele tempo..., por exemplo, a minha tia Pequena, por exemplo, era grande. Sinhá Velha, que era minha tia também. E tinha as moças, em casa, inclusive a minha irmã Lili. Tinha a afilhada da minha tia, a Cicinha; tinha a Ziza, que era filha da... era minha prima; e era essa gente toda, minha família era muito grande (JUMBEBA citado por LOPES, 1992, p. 105).
\end{abstract}

Marinho Jumbeba não hesita em citar inúmeras mulheres interagindo nas rodas de samba e se destacando como partideiras. Além de ressaltar a destreza de algumas mulheres como cantoras, entre em cena um lugar até agora não explorado, a percussão, onde Jumbeba cita Mariquita como pandeirista ${ }^{25}$.

Outra mulher do pandeiro parece ter sido Tia Perciliana do Santo Amaro ${ }^{26}$. Segundo o Dicionário Cravo Albin da Música Popular Brasileira (2010), Perciliana teve 12 filhos, todos ativos no meio musical como, por exemplo, uma de suas filhas que tocava violino; Mané, palhaço de circo e violonista; e João da Baiana, famoso por ter sido um exímio pandeirista e compositor de sambas. Algumas biografias de João da Baiana mencionam que teria sido com sua mãe que João aprendeu a batida característica do pandeiro. Em depoimento ao MIS, ele declara ter sido o responsável pela introdução do pandeiro no samba, informação que foi reproduzida em muitos documentos sobre a história do samba.

Na época, o pandeiro era só usado em orquestras. No samba quem introduziu fui eu mesmo. Isto mais ou menos em 1897, quando eu tinha 8 anos de idade e era Porta-Machado no 'Dois de Ouro' e no 'Pedra de Sal'. Até então as agremiações só tinham tamborim e ainda assim era um tamborim grande e de cabo. 0 pandeiro não era igual ao atual. 0 dessa época era bem maior (JOÃO DA BAIANA citado por VOZES DESASSOMBRADAS DO MUSEU, 1970, p, 59-60).

As informações trazidas por João da Baiana não encontram paralelo na pesquisa de SANDRONI. Segundo o autor,

o acompanhamento rítmico mais comum do samba folclórico até o início do século XX parece ter sido pandeiro, prato-e-faca e palmas. [...] em todas as referências a instrumentos no samba, anteriores a fins da década de 1920, não apenas a cuíca como também o surdo (ou barrica) e o tamborim brilham pela sua ausência (SANDRONI, 2001, p. 179).

Ao parecer, o pandeiro era instrumento de um samba doméstico, aquele praticado no fundo de quintal e na sala de jantar da casa das Tias. 0 que João da Baiana fez foi introduzi-lo nas rodas públicas, na sala de estar da casa das Tias Baianas (frequentada pelos intelectuais e elite), na festa da Penha, nos desfiles dos Ranchos carnavalescos e nas gravadoras. João da Baiana fez com o pandeiro o que Donga fez com o samba Pelo Telefone, ou seja, teve a coragem de expô-los publicamente, ampliando seu domínio.

De todos os modos, o que interessa aqui não é discutir se Perciliana e João da Baiana tiveram o mérito ou não de introduzir estes instrumentos no samba, mas sim, por meio desta relação mãe-filho, apontar uma dimensão mitológica da cultura afro-brasileira que pode, junto com outros elementos (como a ressignificação do lugar das pastoras nos desfiles e a acomodação do samba aos padrões sociais da cultura dominante), ajudar compreender a configuração atual dos papéis masculinos e femininos no complexo mundo do samba. Além da construção histórica ocidental que contribuiu para invisibilizar as mulheres, alguns mitos e crenças das tradições africanas presentes na cultura afro-brasileira podem contribuir para elucidar algumas questões.

De acordo com THEODORO (2008), nas tradições afrobrasileiras a relação das mulheres com a música e com os instrumentos de percussão está vinculada à concepção de 'ritmo vital' do princípio feminino. A autora aponta que na maioria das etnias da África Negra o papel da mulher se delineia a partir da ideia de criação da vida, que se revela desde suas próprias rotinas diárias, que envolvem o nutrir, o organizar a comunidade, até 0 administrar a vida. A mulher negra é, segundo os mitos, 0 elemento básico do ritmo, da dança e da criatividade. No 
Brasil, este princípio está muito presente principalmente no domínio religioso das tradições afro-brasileiras. Diversos mitos das tradições africanas, bem como gregas e indígenas, contam que determinadas funções relegadas aos homens se originaram das mulheres. Elas teriam sido as criadoras e passaram aos homens o conhecimento e a responsabilidade de mantê-lo. Em alguns mitos, este conhecimento não foi passado, mas roubado ou tomado, por vezes, de forma violenta. Esta luta pela supremacia entre os sexos aparece com constância nos mitos de diversas culturas, e podemos encontrá-los em abundância nas mitologias africanas e ameríndias ${ }^{27}$. Segundo ROBERTSON (1989), em muitas culturas onde a performance musical é usada como um modo de controle social, acredita-se que o conhecimento e o poder ritual tenham pertencido em um passado remoto às mulheres.

Nas religiões afro-brasileiras, o Mito lorubá do Tambor Batá é referência importante na determinação dos papéis de gênero desempenhados por homens e mulheres nas práticas musicais dos terreiros. Transcrevo abaixo o mito extraído integralmente do livro Corpo e Ancestralidade de Inaicyra F. dos SANTOS (2006, p. 64), segundo a autora, contado por Ayánkunle Ayánlade e Duroladipo Solaboni, em junho de 1988, na cidade de Oyo, Nigéria.

\begin{abstract}
Nos primórdios da civilização, não existia em Oyo-Oro, cidade desaparecida, nada conhecido com tambor; ali morava uma mulher chamada Ayántoke, mas as pessoas a chamavam de $A y a ́ n^{28}$. Esta senhora era estéril, andava sozinha pelo mato, sempre com um pedaço de madeira oco. Um dia ela viu uma pele de bode e resolveu cobrir as extremidades do pedaço de madeira, mas a pele ora não se adaptava muito bem, ora rasgava quando ela batia com um pedaço de pau. Ela insistiu várias vezes no seu intento; usou também um pedaço de couro em forma de tira para bater nas extremidades do tronco, mas nada dava certo. Finalmente, um dia, Exu apareceu e lhe deu tiras de couro de veado a fim de que amarrasse com firmeza o couro no tronco. E foi nesse momento que o tambor deu um som melodioso. Ayán começou a tocar o tambor por toda cidade, as pessoas corriam para escutá-la (todos surpresos!), porque nunca tinham ouvido alguma coisa semelhante antes... Ela ganhava, ao mesmo tempo, muitos presentes. Xangô orixá do trovão - na qualidade de rei da cidade, quando a ouviu convidou-a para morar no palácio. Ela tornou-se a tocadora oficial do palácio de Xangô. Todos sabiam que ela era estéril; no entanto, mais cedo ou mais tarde ela teria um filho, uma vez que qualquer mulher estéril que entrasse no palácio de Xangô tornava-se fértil. E foi o que aconteceu: Ayán casou-se com Xangô e logo teve um filho que foi chamado de Aseorogi ${ }^{29}$. Ela passou toda a arte de tocar e construir o tambor para o seu filho. Ayántambém é, até hoje, o nome dado a todos os membros de uma família cultuadora do tambor, entre os povos Yorubá. Ayán, portanto, é o símbolo do tambor, orixá dos tocadores e que é cultuado somente por eles.
\end{abstract}

Segundo o Mito do Tambor Batá, as mulheres delegaram a seus filhos homens a arte de tocar e construir o tambor, ficando elas proibidas de exercer esta função. Este tipo de mito, onde a posse original de determinados instrumentos musicais pertencia às mulheres, sendo posteriormente apoderados pelos homens é bastante comum também na região da Amazônia, como é o caso da tribo Wauja pesquisada por MELLO (2005) ${ }^{30}$.
Diversos mitos indígenas, africanos, gregos, cristãos, etc., exercem influência sobre o inconsciente coletivo que gera a música popular brasileira onde, o samba, discutido aqui, é um dos elementos mais representativos. De fato, a música popular brasileira é constituída por tamanho sincretismo que torna difícil qualquer mapeamento relacionado à procedência e influência destes mitos. Não pretendo dar conta desta questão, por isso, agora vou me concentrar apenas em alguns pontos deste mito africano a fim de sugerir possíveis traspassações entre o sagrado e o profano nas manifestações musicais afro-brasileiras, tendo o samba como recorte principal.

\section{7 - 0 domínio da percussão: do terreiro ao samba}

Especialmente por conta do Mito do Tambor Batá, na maioria dos terreiros afro-brasileiros o cargo de ogã, tocador dos atabaques durante os cultos, é exclusivamente masculino. Ainda hoje poucas mulheres ocupam esta função, embora em proporções cada vez maiores, uma vez que esta tradição está passando por constantes resignificações. ${ }^{31}$ Quando há outros instrumentos, a maior parte deles também é tocada por homens, cabendo às mulheres o adjá 32 - que não é usado como instrumento musical - e, eventualmente, o agogô (AMARAL e SILVA, 2008).

Os ogãs não são simplesmente tocadores de atabaques, mas também homens que detêm segredos, rituais e conhecimento só a eles revelados. Têm voz ativa dentro da casa podendo, em certas situações, designar obrigações e ordenar funções. Eles são os detentores dos toques e cantigas específicas para cada situação característica, de modo que sem os ogãs as cerimônias públicas de incorporação e devoção aos orixás raramente acontecem. Por conta disso, possuem um status extremamente prestigiado nas comunidades-terreiros. Segundo SANTOS (2006, p. 69), entre os iorubás na Nigéria o cargo de ogã é transmitido aos homens hereditariamente, enquanto que nos terreiros brasileiros são escolhidos pela lyalorixá ou pelo Babolorixá ${ }^{33}$, sempre levando em conta sua habilidade prévia com o instrumento.

0 terreiro representa uma via de acesso privilegiada à cosmologia e à sociabilidade afro-brasileira visto que é através dele que os mitos se transformam em rito e o tempo cosmológico é recriado e projetado no presente. Os mitos transmitem os valores, princípios, crenças que, através dos ritos, reforçam e moldam o pensamento, a natureza, a forma e a vida da comunidade. 0 mito é compreendido na atividade ritual como uma forma de reconstruir a vida no terreiro, sendo o terreiro entendido não apenas como o espaço religioso, mas como um núcleo e pólo de irradiação para todo o sistema cultural onde seus elementos básicos são incorporados (SANTOS, 2006). Assim, a possibilidade de identificação do sagrado no cotidiano e do cotidiano no sagrado constitui a pedra fundamental das manifestações afro-brasileiras, em 
outras palavras, os limites entre sagrado e profano são frequentemente transponíveis e, por vezes, indistinguiveis.

Em muitos contextos afro-brasileiros o terreiro é o elemento centralizador dos vários eventos e atividades. Em função dele que se articulam as festas, encontros e reuniões de confraternização. 0 samba da virada do século XIX para o XX adquiriu sua forma em constante intercambio com as religiões que se praticavam nos terreiros. Uma festa de samba neste período estava muito próxima a uma festa de umbanda ou candomblé. Uma coisa estava intimamente relacionada à outra de tal modo que havia praticamente uma relação de interdependência. Isto está amplamente indicado na literatura base da música popular brasileira, como em MOURA (1995), M. MOURA (2004), LOPES (1992), PEREIRA (2003), FENERICK, (2005), DOSSIÊ DAS MATRIZES DO SAMBA NO RIO DE JANEIRO (2006), para citar alguns. Lúdico e o litúrgico aconteciam em situações muito próximas, não só física e temporalmente, como também ritual e espiritualmente. Nas casas das Tias Baianas, por exemplo, era lugar onde praticamente tudo acontecia. Os vários depoimentos sobre a disposição geográfica da casa das Tias e organização dos ritos nos diversos espaços da casa são reveladores desta questão. Para citar alguns:

As nossas festas duravam dias, com comida e bebida, samba e batucada. A festa era feita em dias especiais, para comemorar algum acontecimento, mas também para reunir os moços e o povo "de origem". Tia Ciata, por exemplo, fazia festa para os sobrinhos dela se divertirem. A festa era assim: baile na sala de visitas, samba de partido alto nos fundos da casa e batucada no terreiro (JOÃO DA BAIANA citado por MOURA, 1995, p. 83).

Uma época em que não havia clubes dançantes. Os bailes eram feitos em casa de família. Em casa de preto, a festa era na base do choro e do samba. Numa festa de preto havia o baile mais civilizado na sala de visitas, o samba nas salas do fundo e a batucada no terreiro. Era lá que se formavam e se ensaiavam os ranchos (PIXINGUINHA citado por MOURA, 1995, p. 83).

Roberto Moura descreve com riqueza de detalhes o ambiente da casa da Tia Ciata - casa que entrou para a história por meio de seu livro - e, ao mesmo tempo, revela o samba transitando pelos vários ambientes.

[...] uma sala de visitas ampla, onde nos dias de festa ficava o baile, a casa se encompridava para o fundo, num corredor escuro onde se enfileiravam três quartos grandes intervalados por uma pequena área por onde entrava luz, através de uma claraboia. No final, uma sala de refeições, a cozinha grande, e a despensa. Atrás da casa, um quintal com um centro de terra batida para se dançar e depois um barracão de madeira onde ficavam ritualmente dispostas as coisas do culto. Na sala, o baile onde se tocavam os sambas de partido entre os mais velhos, e mesmo música instrumental quando apareciam os músicos profissionais, muitos da primeira geração dos filhos dos baianos, que frequentavam a casa. No terreiro, o samba raiado e, às vezes, as rodas de batuque entre os mais moços. No samba se batia pandeiro, tamborim, agogô, surdo, instrumentos tradicionais que vão se renovando a partir da nova música, confeccionados pelos músicos, ou com o que estivesse disponivel, pratos de louça, panelas, raladores, latas, caixas, valorizados pelas mãos rítmicas do negro. As grandes figuras do mundo musical carioca, Pixinguinha, Donga, João da Baiana, Heitor dos Prazeres, surgem ainda crianças naquelas rodas onde aprendem as tradições musicais baianas a que depois dariam uma forma nova, carioca (MOURA, 1995, p. 102-3).
0 que pretendo destacar com isso é que boa parte das relações, costumes e convenções que caracterizavam os ritos nos terreiros exerceram influência significativa sobre o samba, e vice-versa. Há um intercâmbio, por vezes pouco explorado, entre os ritos dos terreiros e as convenções instituídas no samba e na música popular brasileira. A seguir, vou sugerir possíveis conexões e suas implicâncias no tocante às relações de gênero.

Conforme dito anteriormente, nos terreiros a execução instrumental dos tambores (atabaques) era designada exclusivamente aos homens, por conta do Mito do Tambor Batá. Na casa das Tias Baianas, onde samba e religião se fundia em praticamente um único ritual, os mesmos homens que estavam tocando tambores no terreiro, puxavam os ritmos das rodas de samba na sala de jantar e na sala de visitas. A concepção mitológica de que a execução dos tambores era algo reservada aos homens se transpunha para a realidade do samba praticado naquele contexto, fazendo com que as mulheres integrassem o coro (formando o conjunto feminino que ficou conhecido como pastoras), às palmas, aos improvisos versados, ou aos instrumentos mais leves de percussão, como agogô, prato-e-faca, reco-reco e, mais raramente, ao pandeiro. Essas convenções estabelecidas na casa das Tias se projetaram também no samba praticado nas ruas, nos ranchos e, posteriormente, escolas de samba.

Em entrevista concedida em dezembro de 2005, o jornalista e pesquisador José Carlos Rego, autor de um clássico, A dança do samba, explicou que, nos anos 20, nos primórdios do samba no Rio, os moradores do gueto das favelas ou das vilas operárias, sem recursos para o patrocinio de mínimos conjuntos regionais violão, cavaquinho, pandeiro, flauta - para animar seus encontros musicais, lançavam mão de instrumental próprio ao culto da umbanda, do candomblé ou do jongo, para sua recreação. Isso se dava, em geral, ao final das sessões religiosas que avançavam pela madrugada. No encerramento deles, para relaxar, servia-se comida e sobrevinha a cantoria e o batuque - daí ter sido tão comum a presença de pais-de-santo na liderança dos primeiros grupamentos de samba. [...] Foi dessas primeiras batucadas, rodas e festas que sairam instrumentos que alegrariam partidos-altos, sambas de terreiro e desfiles das escolas (DOSSIÊ DAS MATRIZES DO SAMBA NO RIO DE JANEIRO, 2006, p. 73).

\section{Segundo THEODORO,}

No Rio e Janeiro, as baterias das escolas de samba foram inicialmente formadas pelos alabês [ogãs] das comunidadesterreiros dos bairros a que pertenciam. Assim, cada escola de samba tinha o seu toque característico, por conta de seus ritmistas tocarem para Ogum, Xangô ou Oxossi, já que sendo o tambor a fala dos orixás, cada um tem as suas cantigas e toques próprios. Com a gravação dos sambas em disco e o aperfeiçoamento dos desfiles, as baterias já não se distinguem como antes, sendo que a maneira de tocar e o som de cada escola ficou muito parecido (THEODORO, 2008, p. 166).

De acordo com o documento DOSSIÊ DAS MATRIZES DO SAMBA NO RIO DE JANEIRO, a identidade de cada bateria de escola de samba está relacionada à sua origem - $\mathrm{e}_{\text {, }}$ portanto, aos terreiros de santo.

Nesses terreiros o culto aos símbolos da africanidade estabeleceu diferenciados toques de atabaques, votivos às nações jêje, angola ou keto, de acordo com os orixás que neles baixavam. Como se sabe, 
as vestes, alimentos, cantos de invocação, estilos de dança, guias (colares) e saudações de cada orixá têm identidades próprias. $E_{1}$ da mesma forma, suas batidas de tambores, denominados toques, têm sua propriedade individual. Isto é, há toques de Oxum, de Oxalá, de Ogum, etc. Por extensão, os ogãs - responsáveis pelo setor de ritmo nos terreiros de santo - foram impregnando as baterias do samba da sua habitual frequência, com as caracteristicas de suas casas de santo. Dessa forma surgiram as familias de ritmo das diversas comunidades de sambistas e de suas escolas de samba, o que acabou resultando, também, no pensamento dominante de que cada bateria bate para determinado orixá. Isso igualmente se confirma na existência de fundamentos (essências, pedras, guias, imagens) religiosos implantados ou exibidos em cada terreiro de samba. Dessa forma é que diferenciações ancestrais permaneceram na bateria das escolas ou blocos carnavalescos, retidas na memória coletiva dos grupos responsáveis pelo ritmo (DOSSIÊ DAS MATRIZES DO SAMBA NO RIO DE JANEIRO, 2006, p. 73).

\section{Sobre isso, Marília Barboza da SILVA e Arthur de OLIVEIRA FILHO afirmam:}

\begin{abstract}
No fim dos anos 20, novamente a palavra samba teve a sua significação alterada, outra vez em virtude de ser empregada por uma classe social diferente. Agora eram os descendentes de escravos, reunidos nas chamadas escolas de samba, para os quais a palavra ainda continuava designando a dança de roda de umbigada, de ritmo muito semelhante ao das cerimônias religiosas das macumbas. Samba para eles constituía um ritmo, uma coreografia, um gênero, enfim, muito próximo ao dos pontos de invocação dos orixás afro-brasileiros. Os sambistas primeiros, na esmagadora maioria, eram também pais ou mães-de-santo famosos e temidos: Elói Antero Dias, José Espinguela, Alfredo Costa, Tia Fé, seu Júlio, Juvenal Lopes, dona Ester de Osvaldo Cruz. Os terreiros de samba eram também terreiros de macumba. Cartola, que foi cambono de rua do terreiro de seu Júlio, dizia: "Naquela época samba e macumba era tudo a mesma coisa" (SILVA e OLIVEIRA FILHO citados no DOSSIÊ DAS MATRIZES DO SAMBA NO RIO DE JANEIRO, 2006, p. 65).
\end{abstract}

De acordo com THEODORO (2008), o Mito do Tambor Batá se faz presente de tal modo no contexto das escolas de samba que a Estação Primeira da Mangueira até bem pouco tempo proibia em seu estatuto que as mulheres tocassem na bateria. Hoje, apesar da maioria das escolas contarem com mulheres ritmistas, elas constituem uma parcela bastante pequena, e menor ainda quando se trata de tambores (surdos, caixa, repique). Segundo THEODORO (2008), as escolas do grupo A do Rio de Janeiro, contam com aproximadamente $2 \%$ de mulheres apenas. Em uma pesquisa que realizei recentemente em uma escola de samba de Florianópolis (GOMES e PIEDADE, 2010), pude verificar que a presença de mulheres ritmistas foi bem pequena. A maioria das mulheres se concentrava no naipe dos chocalhos, que se tornou praticamente o naipe feminino desta escola, situação que tem se reproduzido em diversas outras escolas de samba, conforme também observaram PRASS(2004) e OLIVEIRA NETO (2004). Tais fatos revelam que a caracteristica de incluir as mulheres na percussão, e, ao mesmo tempo, concentrar em determinados setores (via dupla de inclusão e exclusão), está se tornando uma tendência nas práticas musicais das escolas de samba de diversas partes o país. ${ }^{34}$

As convenções do samba, ao se inserirem no carnaval do Rio de Janeiro e em diversos outros contextos da sociedade brasileira, levaram consigo grande parte dos fundamentos presentes nos terreiros, conferindo alguns de seus mistérios, fundamentados, em grande parte, na relação com o sagrado. Aqui foram destacados apenas alguns elementos relativos ao campo de poder que envolve as relações de gênero, mas muitos outros aspectos podem ser aprofundados a partir desta perspectiva. A compreensão do que seja "samba" não pode estar limitada à sua classificação como gênero musical; ao contrário, é preciso abranger o conjunto de ações que o definem, considerando que se trata de um movimento nascido no interior das formas religiosas, numa dinâmica própria dos rituais de fé exercitados pelos negros africanos e seus descendentes no Brasil (MATOS, 2007, p. 166).

\section{8 - Considerações Finais}

Os cânones literários que consagraram o samba da "Pequena África do Rio de Janeiro" como uma manifestação musical essencialmente masculina e produzida por homens revelaram uma versão limitada dos acontecimentos. Trata-se de uma narrativa construída sob uma perspectiva patriarcal cujas referências são as histórias dos grandes homens, das grandes obras, dos acontecimentos públicos, das grandes batalhas e disputas políticas, com pouco ou nenhum interesse pelo conhecimento místico, mítico, religioso e espiritual, pela vida privada, e pela história das mulheres. Tais cânones ignoraram a produção de diversas mulheres e minimizaram a importância dos aspectos femininos presentes nos ritos, nos mitos, na religião, no matriarcado que permeia a cultura afro-brasileira.

Examinar o contexto político-social e a relação entre sagrado e profano foram fundamentais para compreender a construção dos papéis de gênero no samba do início do século XX na Pequena África do Rio de Janeiro. Pude verificar que o elevado status social da mulher negra no campo religioso e político exerceu influência significativa na configuração do samba da época. Nas entrelinhas entre o dito e o não dito na construção histórica do samba enquanto manifestação cultural afro-brasileira e como gênero musical brasileiro por excelência, emergiu a centralidade e liderança das Tias Baianas, mulheres negras, mantenedoras das festas realizadas em homenagem aos santos, em encontros com muita comida, música, conversa e trocas culturais. Estas mulheres, ao mesmo tempo em que participaram da história da mulher brasileira, possuem aspectos exclusivamente seus, construindo sua história de mulher negra (THEODORO, 1996, p. 57), com características próprias marcadas por sua ancestralidade africana e outras que adquiriu em função das condições que a realidade local Ihe impôs. Verifiquei, portanto, que a centralidade destas mulheres traspassou o limite da cozinha, da guarda e da orientação espiritual/religiosa - atribuições muito bem documentada na literatura - e adentrou no terreno musical, não apenas como observadoras, apreciadoras, anfitriãs - lugar comumente atribuído a elas -, mas também como cantoras, instrumentistas, compositoras, agentes transformadoras e atuantes num território tido como essencialmente masculino. 
0 coro feminino, elemento sobressalente na condução dos cantos no campo religioso, encontrou sua relação no samba por meio da figura das pastoras, seja nos desfiles dos ranchos e escolas, no samba de terreiro, samba-de-roda, e em muitas outras variantes. No plano instrumental, apontei que a hegemonia masculina nos instrumentos de percussão encontrou conexão, ao menos em parte, com a mitologia africana e convenções dos terreiros. Mas, assim como aconteceu com as pastoras, esta delimitação vem sendo ressignificada de tal modo que a presença de mulheres tem sido cada vez mais frequente entre os ritmistas, tanto no samba como nos terreiros, embora neste último, a resistência seja maior. No campo da composição - por muito tempo mistificado como o lugar masculino por excelência, especialmente na tradição europeia - procurei valorizar fatos que indicam uma possivel relação de Tia Ciata com este exercício. Filo como forma de suspeitar de uma suposta hegemonia masculina neste campo que, a meu ver, reflete mais uma visão condicionada da história - uma história construída à imagem e semelhança da história da música europeia, cuja narrativa se fundamenta na canonização de grandes homens compositores. Mulheres negras compositoras começam a ser apresentadas no samba a partir da década de 70, com as pioneiras Clementina de Jesus, Ivone Lara e Jovelina Pérola Negra. Ao surgirem, foram expostas com naturalidade, como se 50 anos de inexistência pouco representasse. Entretanto, tal ausência de compositoras pode ser traduzida pela palavra invisibilidade, ou seja, a construção histórica e cultural desta ausência.

Ao trazer o complexo mundo do samba carioca para o campo das relações de gênero, as indagações não passaram apenas pela questão das mulheres em cena. Ao analisar este universo, os questionamentos se consolidaram a partir da constatação de que muitos autores veem em tudo que diz respeito ao universo do samba tão somente formas de expressão do masculino. Por isso, ao longo do trabalho emergiu a necessidade de aprofundar a dicotomia homens/mulheres para além de seus corpos e examinar esta complexa relação nos mitos, ritos, crenças, valores, espaços de circulação e meios de produção.

\section{Referências}

A FORÇA FEMININA DO SAMBA.Rio de Janeiro: Centro Cultural Cartola, 2007. Idealização: Nilcemar Nogueira e Helena Theodoro. Coordenação e Edição: Nilcemar Nogueira, José de La Peña Neto e Gisele Macedo. Realização: Centro Cultural Cartola, 2007.

AS VOZES DESASSOMBRADAS DO MUSEU. Depoimentos transcritos de Pixinguinha, João da Baiana e Donga. Museu da Imagem e do Som. Rio de Janeiro: Secretaria da Educação e Cultura - Museu da Imagem e do Som, 1970.

AMARAL, Rita. Mães-de-Santo, mães de tanto: 0 papel cultural das sacerdotisas dos cultos afro-brasileiros. Os Urbanistas:Revista de Antropologia Urbana. Ano 4, v. 4, n. 6, dez/2007. Disponível em: <http://www.aguaforte.com/ osurbanitas6/Amaral2007.html>.

AMARAL, Rita; SILVA, Vagner Gonçalves da.Cantar para Subir:um estudo antropológico da música ritual no candomblé paulista. In: NAU-Núcleo de Antropologia Urbana da USP. Disponivel em: <http://www.n-a-u.org/AmaralctSilva1.

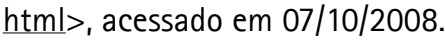

ANDRADE, Mário de. Macunaíma: o herói sem nenhum caráter. Belo Horizonte/Rio de Janeiro: Livraria Garnier, 2004 [1928].

. Música de feitiçaria no Brasil. 2ª Ed. Belo Horizonte: Itatiaia, 2006.

BOURDIEU, Pierre. A distinção: crítica social do julgamento. São Paulo: Edusp; Porto Alegre, RS: Zouk, 2007.

CALDEIRA, Jorge. A construção do samba / Noel Rosa, de costas para o mar. São Paulo: Mameluco, 2007.

CARDOSO FILHO, Marcos Edson. Vozes sem os seus corpos: o som da canção gravada por cantoras no começo do século XX no Brasil. In: CONGRESSO NACIONAL DA ASSOCIAÇÃO NACIONAL DE PESOUISA E PÓS-GRADUAÇÃO EM MÚSICA (ANPPOM) XVII. Anais. Instituto de Artes. Universidade Estadual Paulista (UNESP). 2007. Disponivel em: $<\underline{h t t p: / / w w w . ~}$ anppom.com.br/anais/anaiscongresso_anppom_2007/etnomusic.html>

CUNHA, Fabiana Lopes.Da Marginalidade ao Estrelato: 0 samba na construção da nacionalidade (1917-1945). São Paulo: Annablume, 2004.

CUNHA, Maria Clementina Pereira. Ecos da Folia: uma história social do carnaval carioca entre 1880 e 1920. São Paulo: Companhia das Letras, 2001.

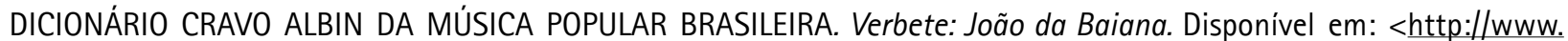
dicionariompb.com.br/joao-da-bahiana>, acessado em: 05/05/2010.

DINIZ, André. Almanaque do Samba: a história do samba, o que ouvir, o que ler, onde curtir. 2a. ed. Rio de Janeiro: Jorge Zahar, 2006.

DOSSIE DAS MATRIZES DO SAMBA NO RIO DE JANEIRO: partido-alto, samba de terreiro, samba enredo. Rio de Janeiro: Centro Cultural Cartola, 2006. Disponivel em: <http://www.cnfcp.gov.br/pdf/Patrimonio_Imaterial/Dossie Patrimonio_Imaterial/Dossie_Samba_RJ.pdf>. 
EFEGÊ, Jota. Figuras e coisas do carnaval carioca. 2a. ed. Rio de Janeiro: Funarte, 2007.

FENERICK, José Adriano. Nem do morro nem da cidade: as transformações do samba e a indústria cultural (1920-1945). São Paulo: Annablume; Fapesp, 2005.

GOMES, Rodrigo Cantos Savelli Gomes. Música, Gênero, Comunidade: uma etnografia no morro do MontSerrat, Morro da Caixa d'Água, Florianópolis, SC. 2008. 126p.Trabalho de Conclusão de Curso. Graduação em Licenciatura em Música. Universidade do Estado de Santa Catarina. 2008.

GOMES, Rodrigo Cantos Savelli; PIEDADE, Acácio T. C. Música, Mulheres, Territórios: uma etnografia da atuação feminina no samba de Florianópolis. Revista Música e Cultura, n. 5, 2010, p.1-15. Disponivelem: <http://musicaecultura.ufsc. br/Gomes_Piedade-Samba.pdf>.

Tias Baianas que lavam, cozinham, dançam, cantam, tocam e compõem: um exame das relações de gênero no samba da Pequena África do Rio de Janeiro na primeira metade do século XX. In: I Simpósio Brasileiro de Pós-Graduandos em Música e XV Colóquio do Programa de Pós-Graduação em Música da UNIRIO. Anais. Rio de Janeiro, 2010.

GOMES, Tiago de Melo. Para Além da Casa da Tia Ciata: outras experiências no universo cultural carioca, 1830-1930. Revista Afro-Ásia, n.29-30, Universidade Federal da Bahia, 2003, p.175-198.

HITA, Maria Gabriela. As casas das mães sem terreiro: etnografia de modelo familiar matriarcal em bairro popular negro da cidade de Salvador. Tese (Doutorado) em Ciências Sociais. Instituto de Filosofia e Ciências Humanas. Universidade Estadual de Campinas. 2004.

JACOB, Adriana. Matriarca do samba.In:Correio da Bahia. 03 dez de 2006. Disponivel em: <http://www.macumba-berlin. de/index.php?option=com docman\&ttask=doc view\&tgid=1>, acessado em: 12/01/2011.

LANDES, Ruth. A cidade das mulheres. 2. ed. Rio de Janeiro: Ed. da UFRJ, 2002.

LOPES, Nei. O Negro no Rio de Janeiro e sua Tradição Musical.Rio de Janeiro: Pallas, 1992.

MATOS, Maria Aparecida Donato. Mãe Baiana, corpo-linguagem: um estudo sobre o mito na cultura do samba do Rio de Janeiro. Tese (Doutorado) Programa de Pós-graduação em Ciência da Literatura (Poética). Faculdade de Letras. Universidade Federal do Rio de Janeiro. 2007.

MCCLARY, Susan. Feminine Endings. Minnesota: University of Minnesota Press, 1991.

MELLO, Maria Ignez Cruz. Música e mito entre os Wauja do alto Xingu.Dissertação (Mestrado) Programa de Pós-Graduação em Antropologia Social. Universidade Federal de Santa Catarina. 1999.

lamurikuma: música, mito e ritual entre os Wauja do Alto Xingu. Tese (doutorado) Programa de Pós-Graduação em Antropologia Social. Universidade Federal de Santa Catarina. 2005.

M. MOURA, Roberto. No princípio era a roda: um estudo sobre samba, partido-alto e outros pagodes. Rio de Janeiro: Rocco, 2004.

MOURA, Roberto. Tia Ciata e a Pequena África do Rio de Janeiro. Rio de Janeiro: 2a Ed. Secretaria Municipal de Cultura, Dep. Geral de Doc. e Inf. Cultural, Divisão de Editoração, 1995.

MUKUNA, Kazadiwa. Contribuição Bantu na música popular brasileira: perspectivas etnomusicológicas. São Paulo: Terceira Margem, 2006.

OLIVEIRA NETO, Paulo Cordeiro de. A pura cadência da Tijuca:um estudo sobre a organização social através da bateria do Grêmio Recreativo Escola de Samba Unidos da Tijuca. Revista Habitus.

IFCS/UFRJ, Rio de Janeiro, v.2, n.1, mar/2004, p.21-30. Disponivel em: <http://www.habitus.ifcs.ufrj.br/2paulo.htm>.

PEREIRA, Carlos Alberto M. Cacique de Ramos: uma história que deu samba. Rio de Janeiro: E-Papers Serviços Ed., 2003.

PRANDI, Reginaldo. Os príncipes do destino: histórias da mitologia afro-brasileira. São Paulo: Cosac Naify, 2001.

PRASS, Luciana. Saberes Musicais em uma Bateria de Escola de Samba:uma etnografia entre os Bambas da Orgia. Porto Alegre: Editora da UFRGS, 2004.

ROBERTSON, Carol E. Poder y Género em lãs ExperienciasMusicales de lãs Mujeres. (1989) In: Las Culturas Musicales: Lecturas de Etnomusicologia. CRUCES, Francisco. (Orgs). Trotta Editora: Madrid, 2001, p.383-412.

SANDRONI, Carlos. Feitiço decente: transformações no samba do Rio de Janeiro, 1917-1933. Rio de Janeiro: Jorge Zahar, 2001.

SANTOS, Inaicyra Falcão dos. Corpo e Ancestralidade:uma proposta pluricultural de dança-arte-educação. 2a. Ed. São Paulo: Terceira Imagem, 2006.

SILVA, Yara da.Tia Carmem.negra tradição da Praça Onze. Rio de Janeiro: Gramond, 2009.

SODRÉ, Muniz. Samba, o dono do corpo. Rio de Janeiro: 2a. Ed. Mauad, 1998.

SOUZA, Márcio Ferreira de. "Ô Abre Alas": as mulheres em cena no nascente mercado fonográfico brasileiro. IN: SEMINÁRIO FAZENDO GÊNERO 7. Simpósio Temático 3: Elas na pauta: mulheres e canções. Anais... Universidade Federal de Santa Catarina. Florianópolis, 2006.

THEODORO, Helena. Mito e espiritualidade: mulheres negras. Rio de Janeiro: Pallas, 1996.

. As muitas mulheres ao tambor. In: NASCIMENTO, Alexandre et al (Orgs). Histórias, Culturas e Territórios Negros da Educação: reflexões docentes para uma reeducação das relações étnico-raciais. Rio de Janeiro: E-pappers, 2008, p.153-177. 
TRAMONTE, Cristiana. A condição negra feminina e a fé religiosa: histórias de resistência, violência e poder. In: SEMINÁRIO INTERNACIONAL FAZENDO GÊNERO 8. Anais. ST1 - a questão racial no Brasil e as relações de gênero.Universidade Federal de Santa Catarina, Florianópolis, 2008.

VELHA GUARDA DA PORTELA EM "O MISTÉRIO DO SAMBA". Direção: Carolina Jabor e Lula Buarque de Holanda. Produção: Leonardo Netto e Lula Buarque de Holanda. DVD (90 min). NTSC. Cor. 2008.

VELLOSO, Mônica Pimenta. As Tias Baianas Tomam Conta do Pedaço: espaço e identidade cultural no Rio de Janeiro.

Estudos Históricos, Rio de Janeiro, v. 3, n. 6, 1990, p.207-228.

VIANNA, Hermano. 0 mistério do samba.Rio de Janeiro: 6 ed. Jorge Zahar, 2007.

WILLIAMS, Alastair. Construting Musicology. Ashgate: Burlington, USA, 2007.

WERNECK, Jurema Pinto. O Samba Segundo as lalodês: mulheres negras e a cultura midiática. Tese (Doutorado) Programa de Pós-Graduação em Comunicação. Universidade Federal do Rio de Janeiro. 2007.

WOORTMANN, K. A familia das mulheres. Rio de Janeiro: Tempo Brasileiro; Brasília: CNPq, 1987.

\section{Notas}

1 Uma versão parcial deste artigo foi publicada nos anais do I Simpósio Brasileiro de Pós-Graduandos em Música, em 2010, quando a pesquisa ainda estava em andamento (ver: GOMES, 2010).

2 A categoria 'arte' está sendo empregada de acordo a teoria do gosto e julgamento proposta por BOURDIEU (2007). 0 autor parte de uma hierarquia socialmente reconhecida das artes, a qual determina a hierarquia social de seus consumidores que, portanto, funciona como um marcador de classes, um dos principais legitimadores das diferenças sociais.

3 Pelo Telefone: Música gravada e registrada na Biblioteca Nacional em 1916, mas alcançou sucesso durante o carnaval de 1917, quando passou a integrar o repertório de diversos blocos carnavalesco da cidade do Rio de Janeiro. Foi registrada em nome de Donga (Ernesto Joaquim Maria) e Mauro de Almeida. A atitude de tentar definir os autores da música gerou grande discordância no mundo do samba. Retornarei a este tema ao comentar sobre a reivindicação de Tia Ciata na autoria desta música.

4 Segundo MCCLARY (1991), há uma vasta produção sobre critica feminina em diversas áreas do conhecimento, muitas das quais anteriores à musicologia feminista. Contudo, não é possivel transferir as questões metodológicas dessas áreas diretamente para a música, pois a música tem especificidades que precisam ser consideradas e respeitadas. Por isso, a autora desenvolveu uma série de pautas, reflexões, métodos e experimentos que podem ser adequados à musicologia, as quais serviram de referência para o presente estudo.

5 Maria das Dores Santos nasceu interior do Rio de Janeiro em 1911. Na década de 1960 tornou-se a segunda esposa de Donga, autor da música Pelo Telefone. Em janeiro e fevereiro de 2003, aos 92 anos, gravou o seu primeiro CD, lançado no dia 22 de setembro de 2003, na Sala Cecilia Meireles.

6 Iranette Ferreira Barcellos, conhecida como Tia Surica, nasceu em 1940. Começou a frequentar a Portela aos 4 anos de idade e hoje é uma das referências da escola. Desde 1980 passou a integrar a Velha-Guarda desta agremiação, onde gravou diversos CDs. No quintal de sua casa - conhecida como o 'Cafofo da Surica' - ela costuma reunir centenas de pessoas para rodas de samba, lembrando as Tias Baianas do início do século XX.

7 Áurea Maria de Almeida Andrade é filha de Manacéa e Dona Neném. Fez sua estreia Portela em 1970 e atualmente é pastora da Velha-Guarda da escola, ao lado de Tia Surica e Neide. É também compositora e, agora que está aposentada, pretende dedicar-se mais a carreira musical.

8 Yolanda de Almeida Andrade, chamada por Dona Neném, nasceu em 1925 e mora em Madureira desde os seis anos de idade. Viúva de Manacéa, com quem esteve casada por 44 anos. Faz parte da história viva da Portela, atuando desde as festas dos fundos de quintais até nas Escolas de Samba, é uma das referências obrigatórias quando se trata relembrar o passado.

9 Maria Moura foi casada por 30 anos com o saxofonista Paulo Moura. É pesquisadora e no terreiro ocupa o posto de Equede (equivante feminino de ogã). Desde 1994 tem feito palestras e conferências sobre a cultura afro-religiosa em diversas regiões do país.

10 Lygia Santos é advogada, pesquisadora, museóloga e professora. Filha de dois ícones da música popular brasileira o compositor Donga e a cantora Zaíra de Oliveira. Publicou em 1980 com Marilia T. Barbosa da Silva, o livro Paulo da Portela - Traço de União entre duas Culturas, pela Editora MEC/ FUNART e foi autora da tese Villa-Lobos e os Choros.

11 Jurema Werneck é formada em Medicina pela Universidade Federal Fluminense. Promoveu a criação da 'Criola', organização voltada para o fortalecimento - ou empoderamento de mulheres, adolescentes e meninas negras. Escreveu a dissertação Samba Segundo as lalodês: mulheres negras e a cultura midiática.

12 Nilcemar Nogueira é neta de Cartola e Dona Zica. Foi uma das responsáveis pela reedição de $A$ Voz do Morro, primeiro jornal comunitário do Rio. Foi a primeira mulher a ocupar o cargo de diretora de harmonia desta escola. É atualmente presidente do Centro Cultural Cartola e foi autora do livro Dona Zica, Tempero, Amor e Arte.

13 Imagens selecionadas em sites diversos da internet.

14 Pequena África foi o nome dado por Heitor dos Prazeres à região do Rio de Janeiro compreendida pela zona portuária, Gamboa, Saúde, Pedra do Sal, locais habitados majoritariamente por negros cariocas e migrantes. 0 termo ficou consagrado na literatura após a publicação do livro de Roberto MOURA (1995), Tia Ciata e a Pequena África do Rio de Janeiro.

15 Há uma grande liberdade no emprego dos termos matriarcal e patriarcal, por este motivo, muitos estudiosos recusam-se a empregá-los. Limitarei sua utilização a partir da definição de RADCLIFFE-BROWN. Segundo o autor, "Uma sociedade pode ser chamada patriarcal, quando a descendência é patrilineal (isto é, os filhos pertencem ao grupo do pai) o casamento é patrilocal (isto é, a mulher muda-se para o grupo local do marido); a herança (ou propriedade) e a sucessão (hierárquica) são em linha masculina, e a família é patripotestal (isto é, a autoridade sobre os membros da família está nas mãos do pai ou seus parentes). Por outro lado, uma sociedade pode ser chamada matriarcal, quando a descendência, herança e sucessão estão na linha feminina, quando o casamento é matrilocal (o marido muda-se para a casa de sua mulher), e quando a autoridade sobre os filhos é exercida pelos parentes da mãe" (RADCLIFFE-BROWN citado por HITA, 2004, p. 13).

16 Ao parecer, não há nenhuma imagem documentada de Tia Ciata, embora diversos sitios da internet especulem que uma das baianas retratadas acima seja ela. De acordo com JACOB (2006) "A maioria dos estudiosos acredita que nenhuma imagem de Hilária tenha sido registrada. Na Bahia, muitos pesquisadores condenam a falta de reverência à mulher que conseguiu assumir, em meio aos senhores do samba, o posto de rainha. 0 nome de Hilária Batista de Almeida não figura na Enciclopédia da Música Brasileira Popular, Erudita e Folclórica, que agrupa mais de 3.500 verbetes".

17 Tia Maria do Adamastor, ou Maria da Conceição César. Carioca de nascimento, recebeu o apelido de 'baiana' devido à sua profunda convivência com os negros vindos do estado nordestino. Participou da fundação de vários ranchos, como o Sempre-Vivas, Flor da Romã e Rei de Ouros, onde frequentemente fazia o papel de mestre-sala (A FORÇA FEMININA DO SAMBA, 2007, p. 19; EFEGÊ, 2007, p. 15-16). 
18 Tia Amélia do Aragão morou na Rua Teodoro da Silva, 44 - onde nasceu seu filho Donga em 1889 - depois na Rua do Aragão, que Ihe deu o apelido de Amélia do Aragão. Foi uma das famosas Tias Baianas da virada do século XX (SILVA, 2009, p. 64; DONGA citado por SODRÉ, 1998, p. 70; A FORÇA FEMININA DO SAMBA, 2007, p. 18).

19 Tia Carmem, conhecida como Carmem do Ximbuca, ou Tia Carmem da Praça Onze. Nasceu em 29 de julho de 1878, foi para o Rio de Janeiro em 1893, onde faleceu em maio 1988, aos 109 anos. Casou-se com Manoel Teixeira, com quem teve 22 filhos, e ficou conhecida como Carmem do Ximbuca, que era o apelido dele. Foi uma das famosas Tias Baianas da virada do século XX (EFEGÊ, 2007, p. 174-6; COSTA citado por SILVA, 2009, p. 18; MOURA, 1995, p. 158).

20 IRANETTE FERREIRA BARCELLOS (Tia Surica). Entrevista concedida ao autor na residência da entrevistada, Rua Júlio Fragoso, Bairro Oswaldo Cruz, Rio de Janeiro - RJ, dia 26 de setembro de 2010 às 10h30min. Duração: 30 minutos.

21 IVONE LARA. Série Depoimento para Posteridade. Museu da Imagem do Som. 30 de junho de 1978.

22 Trecho transcrito por mim do DVD intitulado VELHA GUARDA DA PORTELA EM "O MISTÉRIO DO SAMBA" (2008).

23 ÁUREA MARIA DE ALMEIDA ANDRADE. Entrevista concedida ao autor na residência da entrevistada, Rua Compositor Manacéa, Bairro Oswaldo Cruz, Rio de Janeiro - RJ, dia 23 de setembro de 2010 às 10h30min. Duração: 58 minutos.

24 Imagem disponivel em: <http://www.flickr.com/photos/cariocavoyeur/2851494985/>, acessado em: 07/01/2011.

25 A informação sobre Mariquita como pandeirista também é revelada em no livro de Roberto MOURA (1995, p. 97) e no documento A FORÇA FEMININA DO SAMBA (2007, p. 16).

26 Também encontrei como Perciliana Maria Costança. 0 primeiro nome aparece às vezes como Prisciliana ou Preseiliana.

27 A título de ilustração: na mitologia iorubá encontramos, por exemplo, o mito do guerreiro que toma o poder das mulheres. Segundo o mito, no começo quem mandava no mundo eram as mulheres e os homens eram a elas totalmente submissos. Mas os homens aprenderam a fabricar ferramentas e descobriram que com elas, além de plantar, caçar, etc., podiam matar pessoas. Assim, teriam inventado a guerra, tornaram-se guerreiros, e decidiram tomar para si o domínio que as mulheres controlavam (PRANDI, 2001, p. 55-62). ROBERTSON (1989), por exemplo, descreve a disputa pela supremacia entre os selk'nam, antiga tribo indigena que habitava a ilha da Terra do Fogo. Esta etnia possuía uma intensa espiritualidade, manifestada através de cerimônias mitológicas, como, por exemplo, o hain- ritual de iniciação sexual - onde se revelava, apenas aos adolescentes homens, certos segredos com o objetivo de se preservar a ordem social, ou seja, o poder masculino. Segundo o mito, antigamente, os homens estavam subordinados ao poder que exerciam as mulheres. Elas tomavam as decisões importantes para o melhor desenvolvimento de seu grupo.

28 A ortografia da palavra Ayán, no idioma lorubá, segundo o dicionário R.C Abraham (Inglaterra, London Press, 1958) é Ayòn, que significa tipo de árvore e Deus dos tambores (SANTOS, 2006, p. 155).

29 Aseorogi - o axé (a força, a essência) da árvore e que faz cerimônia e que cuida do tambor (SANTOS, 2006, p. 156).

30 Segundo MELLO (1999 e 2005), entre os índios Wauja do Alto Xingu as mulheres seriam as primeiras "donas" e conhecedoras do repertório das flautas sagradas, só que, neste caso, o privilégio de tocar o instrumento não foi simplesmente transmitido, mas roubado pelos homens, ficando as mulheres proibidas de tocar ou ver estes instrumentos sob pena de sofrer severas sanções.

31 A informação a respeito da hegemonia masculina no cargo de ogã e a tendência atual em estender também para as mulheres, obtive em pesquisa anterior, quando em trabalho de conclusão de curso investiguei sobre as relações de gênero nos terreiros do Morro da Caixa d'Água de Florianópolis, ver: GOMES (2008). Para tal, tomei como referência as entrevistas com os frequentadores dos terreiros, observações em campo e os estudos de AMARAL (2007) e TRAMONTE (2008).

32 Adja é um sino constituído de uma a sete campânulas cuja principal atribuição é provocar o transe quando agitado sobre a cabeça do iniciado, de uso reservado aos pais ou mães-de-santo e as ekedes, não sendo necessário o domínio de qualquer técnica específica.

33 Yalorixá e Babolorixásão os responsáveis pelo ritual, são os "zeladores" dos orixás (SANTOS, 2006, p. 156).

34 Ả parte dos chocalhos, a presença de mulheres em outras funções nas baterias das escolas é rara. Por vezes, é possivel encontrá-las no tamborim, cuica, agogô, enquanto que no repique, caixa e, principalmente, no surdo, é ainda mais raro. 0 próprio DOSSIÊ DAS MATRIZES DO SAMBA NO RIO DE JANEIRO, ao descrever cada um dos instrumentos de uma escola de samba, faz uma descrição graciosa, relacionando o chocalho às mulheres. Segue a seguir: "Pratinelas: Placas de metal, redondas e furadas, interligadas por arame ou madeira pontiagudos. Construidas na vertical ou horizontal, quando sacudidas produzem agradáveis sons metálicos. Deve-se a elas o aparecimento da mulher na bateria do samba. Emite sons agudos" (op.cit., p. 75). 0 Dossiê chama este instrumento de pratinelas como forma de diferenciar do chocalho usado nas rodas de samba, feito de madeira e sementes dentro.

Rodrigo Cantos Savelli Gomes é Mestre em Música (Musicologia-Etnomusicologia) pela Universidade do Estado de Santa Catarina e graduado pelo Curso de Licenciatura em Música na mesma instituição. Trabalha como Professor Efetivo da Prefeitura Municipal de Florianópolis, onde leciona a disciplina Artes/Música para o Ensino Fundamental; e como Tutor do Curso de Graduação em Educação Musical da Universidade Federal de São Carlos. Atua como pianista e diretor musical de grupos religiosos, corais e bandas. As últimas pesquisas enfocaram as relações de gênero na música popular brasileira, em especial no samba. Em 2008 recebeu o 3 Prêmio Construindo a Igualdade de Gênero e foi condecorado com Menção Honrosa no ano consecutivo pelo mesmo concurso. 